\title{
Low-grade glioma with novel mutations in KRAS and PMS2 in an adolescent with Down syndrome
}

\author{
Jason W Adams, ${ }^{1}$ Denise Malicki, ${ }^{2}$ Michael Levy, ${ }^{3}$ John Ross Crawford ${ }^{4}$
}

${ }^{1}$ Neurosciences, University of California San Diego, La Jolla, California, USA

2Pathology, Rady Children's Hospital University of California San Diego, San Diego,

California, USA

${ }^{3}$ Neurosurgery, University of California San Diego, San Diego, California, USA

${ }^{4}$ Neurosciences and Pediatrics, University of California San Diego, San Diego, California, USA

\section{Correspondence to Dr John Ross Crawford; jrcrawford@ucsd.edu}

Accepted 20 July 2021

Check for updates

(c) BMJ Publishing Group Limited 2021. No commercial re-use. See rights and permissions. Published by BMJ.

\begin{tabular}{|l|}
\hline To cite: Adams JW, \\
Malicki D, Levy M, et al. BMJ \\
Case Rep 2021;14:e245456. \\
doi:10.1136/bcr-2021- \\
245456 \\
\hline
\end{tabular}

\section{DESCRIPTION}

A 12-year-old boy with Down syndrome (DS), myeloproliferative disorder and autism spectrum disorder presented for new-onset seizures. The patient did not report any headaches, weakness, nausea or vomiting, and neurological examination was non-focal. MRI revealed a mixed solid and cystic $13 \mathrm{~mm}$ mass with surrounding vasogenic oedema immediately lateral to the posterior horn of the left lateral ventricle in the periatrial white matter (figure 1). The mass lesion was similar in appearance to the adjacent choroid plexus cyst and demonstrated contrast enhancement without reduced diffusivity. Neuroradiographic differential diagnosis included low-grade astrocytoma, gangliocytoma or ganglioglioma. The patient underwent robotic-guided biopsy and laser ablation. Neuropathology revealed a hypercellular tumour with angiocentric proliferation consisting of spindle-shaped to ovoid-shaped cells with pale cytoplasmic nuclei and scattered inclusions. Denser areas of the neoplasm, comprising astrocytes with a dense fibrillar matrix, contrasted with looser areas consisting of more widely spaced cells separated by an oedematous to myxoid stroma (figure 2). Scattered Rosenthal fibres and eosinophilic granular bodies were observed, as well as rare mitotic figures. No significant necrosis was appreciated. Immunohistochemistry showed diffuse positivity for glial fibrillar acidic protein and weak positivity for synaptophysin. Sparse (1\%-2\%) tumour nuclei stained $\mathrm{Ki} 67+$. Immunostaining for epithelial membrane antigen was negative. Next-generation sequencing (NGS) revealed three novel clinically significant variants, two in KRAS (c.64C>A and c.35G >C) and one in PMS2 (c.538$2 \mathrm{~A}>\mathrm{G})$. NGS likewise detected multiple variants of unknown clinical significance, within genes including TAF1, RARA, DNMT3A, ITK, KIF5B, CHD4, AKT1 and GRIN2A; no BRAF mutation or fusion was detected. Microarray analysis was consistent with constituent trisomy 21 but otherwise detected no clinically significant abnormalities. The complete neuropathological profile was most consistent with a diagnosis of low-grade glioma (WHO grade I), histologically favouring pilocytic astrocytoma. Follow-up imaging has shown no evidence of residual or recurrent tumour within 18 months after laser ablation, and the patient remains seizure-free on anticonvulsant medication.

DS is associated with an altered neoplastic risk profile and may influence the frequency of particular types of brain tumours. ${ }^{1-6}$ Cases of glioma in DS occur rarely, ${ }^{23-11}$ and whether DS affects glioma behaviour is unclear. We present a rare case of

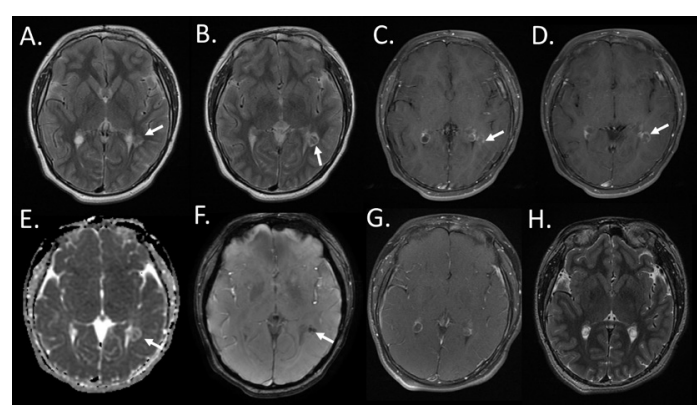

Figure 1 Neuroimaging features of a low-grade glioma in a patient with Down syndrome. T2-weighted MRI ( $A$, $B$ ) reveals a left-sided periventricular hypointense mass (arrows) adjacent to a choroid plexus cyst with rim-like enhancement (C, D) on postgadolinium sequences, no evidence of reduced diffusivity on apparent diffusion coefficient sequences $(E)$ and susceptibility weighted artefact (F). The tumour had similar appearance as the normal adjacent choroid plexus cysts $(\mathrm{G}, \mathrm{H})$.

low-grade glioma with novel KRAS and PMS2 mutations in an adolescent with DS. Low-grade gliomas nearly exclusively harbour mutations that upregulate the Ras/MAPK pathway. ${ }^{12-15}$ Of these, only a slight proportion $(<1 \%)$ involves the pathway effector $K R A S,{ }^{16}$ heightening surprise at the dual novel KRAS mutations observed in the present case. Mutation of the DNA mismatch repair gene PMS2 has previously been documented in hypermutated paediatric high-grade glioma, ${ }^{17}$ suggesting that its

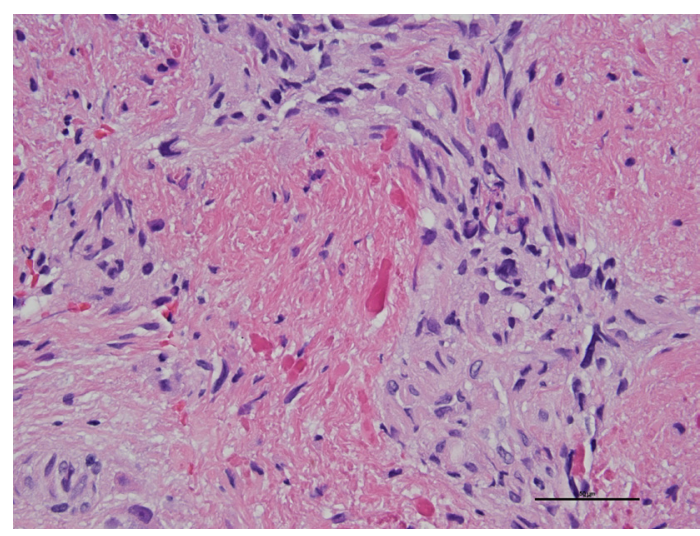

Figure 2 Neuropathology of a low-grade glioma in a patient with Down syndrome. H\&E-stained section showing a low-grade glial neoplasm characterised by a proliferation of elongate cells with mildly pleomorphic and variably hyperchromatic nuclei growing predominantly in perivascular spaces, accompanied by Rosenthal fibre formation. A rare mitotic figure was seen. $400 \times$ magnification. 
mutation in the low-grade neoplasm here may be permissive of mutational burden. Future investigation should further explore the mutational landscape of glioma in DS.

\section{Learning points}

- Low-grade gliomas are nearly universally associated with mutations in the Ras/MAPK pathway, but mutations in KRAS comprise a very small proportion $(<1 \%)$

- The occurrence of central nervous system tumours in association with Down syndrome is rare, and the mechanism of the role, if any, for trisomy 21 is unclear.

- We report the case of low-grade glioma with a unique molecular profile in association with Down syndrome, expanding the genetic complexity of low-grade glioma.

Contributors JWA, DM, ML and JRC were responsible for the design and creation of the manuscript.

Funding The authors have not declared a specific grant for this research from any funding agency in the public, commercial or not-for-profit sectors.

Competing interests None declared.

Patient consent for publication Obtained.

Provenance and peer review Not commissioned; externally peer reviewed.

\section{REFERENCES}

1 Satgé D, Stiller CA, Rutkowski S, et al. A very rare cancer in Down syndrome: medulloblastoma. epidemiological data from 13 countries. J Neurooncol 2013:112:107-14.
2 Satgé D, Monteil P, Sasco AJ, et al. Aspects of intracranial and spinal tumors in patients with Down syndrome and report of a rapidly progressing grade 2 astrocytoma. Cancer 2001;91:1458-66.

3 Ehara $\mathrm{H}$, Ohno K, Ito H. Benign and malignant tumors in Down syndrome: analysis of the 1514 autopsied cases in Japan. Pediatr Int 2011;53:72-7.

4 Satgé D, Sommelet D, Geneix A, et al. A tumor profile in Down syndrome. Am J Med Genet 1998;78:207-16.

5 Hasle $\mathrm{H}$, Clemmensen IH, Mikkelsen M. Risks of leukaemia and solid tumours in individuals with Down's syndrome. Lancet 2000;355:165-9.

6 Hill DA, Gridley G, Cnattingius S, et al. Mortality and cancer incidence among individuals with Down syndrome. Arch Intern Med 2003;163:705-11.

7 Narod SA, Stiller C, Lenoir GM. An estimate of the heritable fraction of childhood cancer. Br J Cancer 1991:63:993-9.

8 Miller RW. Relation between cancer and congenital defects in man. N Eng/ J Med 1966;275:87-93.

9 Petruzzellis G, Valentini D, del Bufalo F, et al. Vemurafenib treatment of pleomorphic xanthoastrocytoma in a child with Down syndrome. Front Oncol 2019:9:1-6.

10 Holland WW, Doll R, Carter CO. The mortality from leukaemia and other cancers among patients with Down's syndrome (mongols) and among their parents. $\mathrm{Br}$ J Cancer 1962;16:177-86.

11 Satgé D, Sasco AJ, Chompret A, et al. A 22-year French experience with solid tumors in children with Down syndrome. Pediatr Hematol Oncol 2003;20:517-29.

12 Zhang J, Wu G, Miller CP, et al. Whole-Genome sequencing identifies genetic alterations in pediatric low-grade gliomas. Nat Genet 2013;45:602-12.

13 Jones DTW, Hutter B, Jäger N, et al. Recurrent somatic alterations of FGFR1 and NTRK2 in pilocytic astrocytoma. Nat Genet 2013;45:927-32.

14 Collins VP, Jones DTW, Giannini C. Pilocytic astrocytoma: pathology, molecular mechanisms and markers. Acta Neuropathol 2015;129:775-88.

15 Ryall S, Zapotocky M, Fukuoka K, et al. Integrated molecular and clinical analysis of 1,000 pediatric low-grade gliomas. Cancer Cell 2020;37:569-83.

16 Ryall S, Tabori U, Hawkins C. Pediatric low-grade glioma in the era of molecular diagnostics. Acta Neuropathol Commun 2020;8:1-22.

17 Johnson A, Severson E, Gay L, et al. Comprehensive genomic profiling of 282 pediatric low- and high-grade gliomas reveals genomic drivers, tumor mutational burden, and hypermutation signatures. Oncologist 2017;22:1478-90.

Copyright 2021 BMJ Publishing Group. All rights reserved. For permission to reuse any of this content visit

https://www.bmj.com/company/products-services/rights-and-licensing/permissions/

BMJ Case Report Fellows may re-use this article for personal use and teaching without any further permission.

Become a Fellow of BMJ Case Reports today and you can:

- Submit as many cases as you like

- Enjoy fast sympathetic peer review and rapid publication of accepted articles

- Access all the published articles

Re-use any of the published material for personal use and teaching without further permission

Customer Service

If you have any further queries about your subscription, please contact our customer services team on +44 (0) 2071111105 or via email at support@bmj.com.

Visit casereports.bmj.com for more articles like this and to become a Fellow 